\title{
6. The (non)instrumental character of unpaid internships: Implications for regulating internships ${ }^{1}$
}

\author{
Wil Hunt and Charikleia Tzanakou
}

\subsection{INTRODUCTION: GRADUATE INTERNSHIPS IN THE UK CONTEXT}

Internships have become an established feature of the UK graduate labour market and the issue of unpaid internships has dominated media and policy discussions about social mobility and access to key professions and industries. ${ }^{2}$ Figures from the most recent Destination of Leavers from Higher Education survey (DLHE) show that 6970 leavers from UK higher education institutions in 2016-17 were engaged in an internship six months after leaving university ( 2 per cent of those in employment). ${ }^{3}$ This rises to 7560 ( 2.5 per cent) when 'hidden' internships - internships reported as 'voluntary' positions while not being in the voluntary sector or occupations associated with work for a good

1 The research for this chapter was supported by a UK Economic and Social Research Council grant [ES/M500604/1] and a PhD studentship bursary and internal research project grant from Portsmouth Business School. The authors would also like to acknowledge the Higher Education Statistics Agency for supplying the DLHE data.

2 Social Mobility Commission, State of the Nation 2018-19: Social Mobility in Great Britain (Her Majesty's Stationery Office 2019); Rebecca Montacute, 'Internships - Unpaid, Unadvertised, Unfair' (2018) Sutton Trust Research Brief 20; Carys Roberts, The Inbetweeners: The New Role of Internships in the Graduate Labour Market (Institute for Public Policy Research 2017); Alan Milburn, Unleashing Aspiration: Final Report of the Panel on Fair Access to the Professions (Stationery Office 2009).

3 The DLHE is a census of UK and EU domiciled graduates from UK higher education institutions. The survey captures information about graduates' labour-market activity at six months after leaving their course and asks about their main job (or further study), how they found out about their main job and motivations for taking it, and reflections on their course. 
cause - are taken into account. ${ }^{4}$ Even this is likely to be an underestimate as the DLHE is only a snapshot of graduates' main job at six months after graduation, while many graduates engage in internships as a second job or more than six months after graduation. A separate survey of 2011-12 creative arts and mass communications and documentation graduates showed that 26 per cent had engaged in at least one graduate internship during the first two years after graduation, ${ }^{5}$ and a YouGov survey of graduates in their twenties showed that 39 per cent had done at least one internship at some time. ${ }^{6}$

Despite the prevalence of graduate internships and the apparent interest in policy debates, there remains no formal definition of the practice, either in research or UK law. A number of terms such as 'industrial placement', 'volunteer worker' and 'work placement' have been used to describe internships. Likewise, the term 'internship' has been used to describe a range of different types of work experiences ranging from the mundane to the developmental, at different points in a student's or graduate's trajectory and in different national contexts. Tasks can range from stuffing envelopes or shuttling coffee in a newsroom, to more structured and developmental experiences, such as contributing to news stories or live advertising campaigns. ${ }^{8} \mathrm{O}$ 'Higgins and Pinedo, among others, distinguish three main uses for the term, while noting that there may at times be some overlap between these:

1. Work experience undertaken as part of an active labour-market programme.

2. Internships linked to a course of academic study (traditionally termed work placements or sandwich placements in the UK).

3. Open-market internships - work placements or experience in organizations that do not fit the previous two categories. ${ }^{9}$

4 Wil Hunt, Participation in Paid, Unpaid and 'Hidden' Internships at Six Months after Graduation: Are Some Graduates Excluded? (SRHE 2020).

5 Wil Hunt, 'Internships and the Graduate Labour Market' (PhD thesis, University of Portsmouth 2016).

6 Carl Cullinane and Rebecca Montacute, Pay As You Go? Internship Pay, Quality and Access in the Graduate Jobs Market (Sutton Trust 2018).

7 Chartered Institute of Personnel and Development (CIPD), Internships: To Pay or Not to Pay? (CIPD 2010).

8 Ross Perlin, Intern Nation: How to Earn Nothing and Learn Little in the Brave New Economy (rev edn, Verso Books 2012); Charlotte McLeod, Stephanie O'Donohoe and Barbara Townley, 'Pot Noodles, Placements and Peer Regard: Creative Career Trajectories and Communities of Practice in the British Advertising Industry' (2011) 22 Brit J Management 114; Milburn (n 2); Alexandre Frenette, 'Making the Intern Economy' (2013) 40 Work \& Occupations 364.

9 Niall O'Higgins and Luis Pinedo, 'Interns and Outcomes: Just How Effective are Internships as a Bridge to Stable Employment?' (2018) ILO Employment Working Paper No 241. See also Chapter 2 in this volume. 
The above categorization has merit because it enables a demarcation between very different types of experiences; especially between internships (work placements) linked to a course of academic study and open-market internships. These experiences are not only treated differently in UK law, but have different practical implications for employability. Work placements in the UK are supported by the student's institution of study (at least in theory), are often eligible for student finance (although sometimes at a different rate) and normally provide academic credit for the course. ${ }^{10}$ These governed internships tend to be more structured than open-market internships and so may be more likely to be developmental. ${ }^{11}$

The timing here may also be important, especially when national contexts are compared. In Europe and the USA the terms 'internship', 'traineeship' or 'stages' are used in different contexts to refer to both post- and pre-graduation experiences (either linked to a higher education course or otherwise). ${ }^{12}$ In the UK, until recently, the term 'internship' has tended to be reserved for post-graduation experiences. ${ }^{13}$ In this chapter, while recognizing that some open-market internships may occur prior to graduation, we focus on those carried out after graduation for analytical purposes, to avoid conflating the potential differences in employability implications attributed to pre-graduation internships. In contrast, Chapter 4 of this volume focuses on pre-graduation internships undertaken during higher education to allow comparisons between Italy and the UK. Thus, in this chapter we use the term 'graduate internships' for open-market internships carried out after leaving university.

\footnotetext{
10 Kayte Lawton and Dom Potter, Why Interns Need a Fair Wage (Institute for Public Policy Research 2010).

${ }^{11}$ David Lain, Kari Hadjivassiliou, Antonio Corral Alza, Iñigo Isusi, Jacqueline O'Reilly, Victoria Richards and others, 'Evaluating Internships in Terms of Governance Structures: Contract, Duration and Partnership' (2014) 38 Eur J Training Devt 588.

12 TNS Political \& Social, The Experience of Traineeships in the EU (Flash Eurobarometer 378, Directorate-General for Employment, Social Affairs and Inclusion, European Commission 2013).

${ }_{13}$ Chartered Institute of Personnel and Development (CIPD), Internships that Work: A Guide for Employers (CIPD 2015); Perlin (n 8); Oakleigh Consulting and CRAC, Increasing Opportunities for High Quality Higher Education Work Experience (Higher Education Funding Council England 2011).
} 


\subsection{THE LEGAL POSITION OF GRADUATE AND OTHER OPEN-MARKET INTERNSHIPS IN THE UK}

Despite the previously mentioned interest in graduate internships in policy debates, ${ }^{14}$ two tribunal cases ${ }^{15}$ and at least two parliamentary debates on the position of internships vis-à-vis national minimum wage (NMW) legislation, ${ }^{16}$ the legal position of internships remains ambiguous.

The current UK approach to the regulation of open-market internships has been characterized by the use of soft law, ${ }^{17}$ whereby the government has 'sought to influence the use and content of internships, without directly regulating them'. ${ }^{18}$ This has mainly been attempted via the publication of best practice guidance for employers, which typically reminds employers of their obligations under particular work regulations and encourages them to adopt good practice. ${ }^{19}$

As Stewart and others note, the extent to which rights and protections under UK law extend to open-market internships depends on whether a given intern would be considered under law to be a 'worker' or an 'employee', depending upon the particular regulation to be applied (for example, NMW, holiday pay, or health and safety regulations). ${ }^{20}$ Ultimately, this often comes down to whether an employment relationship is adjudged to have been in place.

The most hotly debated issue in relation to internships is whether open-market internships should be paid. While internships are not specifically mentioned

14 Eg Milburn (n 2); Lawton and Potter (n 10); CIPD, Internships (n 7); CIPD, Internships that Work (n 13); Montacute (n 2); Roberts (n 2).

15 See Andrew Stewart and Rosemary Owens, Experience or Exploitation? The Nature, Prevalence and Regulation of Unpaid Work Experience, Internships and Trial Periods in Australia (Fair Work Ombudsman 2013) 228-30.

16 HC Deb 4 November 2016, vol 616, cols 1195-213 (National Minimum Wage (Workplace Internships) Bill); HL Deb 18 December 2017, vol 787, cols 1825-7 (Unpaid Internships).

17 Rosemary Owens and Andrew Stewart, 'Regulating for Decent Work Experience: Meeting the Challenge of the Rise of the Intern' (2016) 155 Int Lab Rev 679; Andrew Stewart, Rosemary Owens, Anne Hewitt and Irene Nikoloudakis, 'The Regulation of Internships: A Comparative Study' (2018) ILO Employment Policy Department Working Paper No 240.

18 Owens and Stewart (n 17) 699.

19 Gateways to the Professions Collaborative Forum, Common Best Practice Code for High-Quality Internships (TUC 2013); National Council of Voluntary Organisations, Voluntary Internships in the Voluntary Sector: Review and Guidance (NCVO 2015), http://knowhownonprofit.org/people/volunteers-and-your-organisation/ NCVOVolunteerInternshipsintheVoluntarySector.pdf, accessed 30 March 2021.

20 Stewart and others (n 17). 
in NMW legislation, work experience carried out while at school and work experience linked to a course of higher or further education are explicitly exempt from NMW regulations. ${ }^{21}$ Volunteers or voluntary workers are similarly excluded from coverage of the NMW in the legislation. ${ }^{22}$ This exclusion was intended to allow individuals to give their time freely to good causes. ${ }^{23}$ In contrast, the primary aim of internships is to be able to gain experience in order to work towards a particular career goal. ${ }^{24}$ There may be some overlap between the two, particularly where interns hope to establish a career in the voluntary sector. ${ }^{25}$

A voluntary worker is defined in NMW legislation as 'a worker employed by a charity, a voluntary organisation, an associated funding body or a statutory body'. ${ }^{26}$ A volunteer, however, is not so clearly defined and this exemption is often exploited in order to justify the non-payment of open-market internships. ${ }^{27}$ Examples of these volunteers, found in the DLHE data used in the analysis described later in this chapter, include clothing designers, management consultants, and graduates working in publishing, financial services and music and film production. It has been described as 'a significant loophole' that makes it 'perfectly legal to employ an intern without paying them' ${ }^{28}$ Official guidance suggests that volunteering applies when the individual has no contract (express or implied), is under no obligation to carry out work and does not expect to receive any reward. ${ }^{29}$ Lawton and Potter note that in most cases it is likely that interns are expected to turn up at particular times and perform specific tasks, and so an unwritten agreement exists. ${ }^{30}$ This was the finding of two test cases that were taken to the Employment Tribunal in

\footnotetext{
21 National Minimum Wage Act 1998, s 3(1a).

22 Ibid s 44(1).

23 Department for Business, Innovation and Skills, Internships and the National Minimum Wage: Frequently Asked Questions (DBIS 2009); Douglas Pyper, 'The National Minimum Wage: Volunteers and Interns' (2015) House of Commons Library Briefing Paper No 00697.

${ }^{24}$ Eg Perlin (n 8); Gateways to the Professions Collaborative Forum (n 19); Oakleigh Consulting and CRAC (n 13).

${ }_{25}$ Pauline Leonard, Susan Halford and Katie Bruce, “"The New Degree?" Constructing Internships in the Third Sector' (2016) 50 Soc 383.

26 National Minimum Wage Act 1998, s 44(1).

27 Owens and Stewart (n 17); Council Recommendation of 10 March 2014 on a Quality Framework for Traineeships [2014] OJ C88/1.

28 CIPD, Internships (n 7) 12.

29 Department for Business, Innovation and Skills (n 23).

30 Lawton and Potter (n 10).
} 
the UK - Vetta v London Dreams Motion Pictures ${ }^{31}$ and Hudson v TPG Web Publishing $L t d^{32}-$ in which back pay was awarded. ${ }^{33}$

There have been two recent attempts to bring internships explicitly within NMW legislation. However, both of these failed as Members of Parliament who supported the practice of unpaid internships talked the motion out. ${ }^{34}$ The invaluable nature of unpaid internships in helping young people get a foothold in a career were invoked as a justification for not bringing the practice explicitly within NMW legislation, and these Members of Parliament did not want to prevent employers from offering these valuable experiences to young aspirants. $^{35}$

This raises the question of how invaluable and instrumental unpaid internships really are in helping labour-market entrants access better jobs. While there is some evidence that work placements carried out as part of a higher education course may improve the labour-market outcomes for participants, ${ }^{36}$ reliable evidence on the outcomes of engaging in open-market internships in the UK has been relatively thin. ${ }^{37}$ Two evaluations of government-backed graduate internship schemes suggested that unpaid open-market internships after graduation improve the labour-market outcomes for interns. ${ }^{38}$ However, the analysis of these studies failed to control for wider factors (personal background, grades and institutional reputation) when attributing outcomes. A Sutton Trust study suggested that pay premiums associated with intern-

\section{[2009] UKET 2703377/08.}

[2011] UKET 2200565/11.

See Stewart and Owens (n 15).

A process by which MPs deliberately continue debating a 'private members Bill' put to the house until the allotted time for debate runs out before the debate can conclude with a vote. This is otherwise known as 'filibustering'. See Tom Bateman, 'Talking Out: How MPs Block Private Members' Bills' BBC News (7 November 2016), https://www.bbc.com/news/uk-politics-37845980, accessed 30 March 2021.

35 HC Deb 4 November 2016, vol 616, cols 1156-1226.

36 Eg Ruth Brooks and Paul Youngson, 'Undergraduate Work Placements: An Analysis of the Effects on Career Progression' (2016) 41 Stud Higher Educ 1563; N Wilton, 'The Impact of Work Placements on Skills Development and Labour Market Outcomes for Business and Management Graduates' (2012) 37 Stud Higher Educ 603; Shiona Chillas, Abigail Marks and Laura Galloway, 'Learning to Labour: An Evaluation of Internships and Employability in the ICT Sector' (2015) 30 New Tech, Work \& Empl 1.

37 Deanna Grant-Smith and Paula McDonald, 'Ubiquitous Yet Ambiguous: An Integrative Review of Unpaid Work' (2018) 20 IJMR 559; O’Higgins and Pinedo (n 9).

38 Robin Mellors-Bourne and Emma Day, Evaluation of the Graduate Talent Pool Scheme (Research Paper No 28, Department of Business, Innovation and Skills 2011); Oakleigh Consulting and CRAC (n 13). 
ships (paid or unpaid) held up when controlling for gender, age, location and socio-economic class, although the data was not presented in the report. ${ }^{39}$

Conversely, a number of studies have raised the prospect that unpaid internships may not be so instrumental in accessing the best jobs. Purcell and others found that, while unpaid work carried out while studying improves the chances of having a graduate job one to two years after graduation, unpaid work after graduation has a negative effect on the chances of having a graduate job. ${ }^{40}$ Similarly, Holford found that unpaid work in professional and associate professional occupations six months after graduating had a negative effect on pay three years later. ${ }^{41}$

In this chapter we look at the early career experiences of graduates and draw out the implications for regulating internships in the UK. The findings show that unpaid graduate internships may not be so instrumental in helping interns access graduate jobs, and question the justification for excluding them from NMW and other employment legislation.

\subsection{DATA AND METHODS}

This chapter draws on quantitative and qualitative data from two separate projects exploring the relationships between higher education participation, access to work experience and early career development of graduates: Paths 2 Work $^{42}$ and a PhD study looking at the role of graduate internships in the UK labour market. ${ }^{43}$

The latter was a primarily quantitative study incorporating secondary analysis of the DLHE for the 2011-12 graduating cohort and a primary survey of creative and mass communications graduates (the Creative Graduates Careers Survey, CGCS). The DLHE analysis of UK- and EU-domiciled graduates from undergraduate and postgraduate courses examined participation in internships at six months after graduation, motivations towards and access routes to internships, and whether interns felt their qualification was needed for the role. The CGCS was a probability survey of UK- and EU-domiciled creative and

\footnotetext{
39 Cullinane and Montacute (n 6).

40 Kate Purcell, Peter Elias, Gaby Atfield, Heike Behle, Ritva Ellison, Daria Luchinskaya and others, Futuretrack Stage 4: Transitions into Employment, Further Study and Other Outcomes (Higher Education Careers Services Unit 2012).

${ }_{41}$ Angus Holford, 'Access to and Returns from Unpaid Graduate Internships' (2017) IZA Institute of Labor Economics Discussion Paper No 10845.

42 Kate Purcell, Peter Elias, Anne Green, Gaby Atfield, Arlene Robertson, Noel Whiteside and others, Present Tense, Future Imperfect: Young People's Pathways into Employment (ESRC 2017).

43 Hunt, 'Internships' (n 5).
} 
mass communications graduates who had graduated from first degree courses at 12 higher education institutions from around the UK $(n=616)$. Institutions participating in the survey were a mix of pre- and post-1992 universities and specialist arts institutions, with a broad regional coverage of England, Scotland and Wales, all with significant provision in creative arts and mass communications subject areas. These subject areas were selected because analysis of DLHE data showed they were subject areas with high participation rates in graduate internships, yet without the established pathways into employment enjoyed by subjects such as medicine. Graduates from the 2007-08, 2009-10 and 2011-12 graduating cohorts were surveyed six, four and two years after graduating, respectively. The survey asked about internships and work activities at the time of the survey and since graduation, and covered job and career satisfaction and views of different forms of employment. While the estimated response rate was relatively low (7.4 per cent) when compared with the wider population of creative and mass communications graduates, the sample was broadly representative in gender, age, ethnicity, domicile and subject area.

Paths2Work was an interdisciplinary project on precarious pathways to employment for young people, completed in 2017, involving follow-up interviews in 2014-15 with 100 survey respondents from Futuretrack ${ }^{44}$ five to six years after they graduated. Those interviewed were UK domiciled; were 21 or younger when they applied to attend university; had lived, studied or worked in the East and West Midlands; and had some experience of unpaid work or other work experience related to their career aspirations as students or after graduation. Interviewees were asked about their current activity, work history since graduating, work experiences before and during university, and future aspirations. The interviews lasted 30 to 60 minutes. They were recorded (with permission), transcribed and analysed thematically using NVivo. The qualitative analysis used in this research draws on a subsample of six who reported experience of open-market internships after graduation and an additional four interviewees who, although they had not reported the experience of an internship, provided useful insights about internships in relation to careers and employment. The qualitative data provided rich accounts of their work history during and after higher education, including quotations pertinent to the

44 Futuretrack is a national longitudinal survey of individuals who applied in 2005-06 for full-time undergraduate degree programmes, covering all UK higher education applicants, involving the collection and analysis of data over a five-and-a-half-year period, from the point at which aspiring students applied to enter higher education in 2005-06 until winter 2011-12. Online surveys were conducted with respondents at four stages: when they were applicants in spring-summer 2006, in summer 2007 one year on, in autumn 2009 (repeated for those on four-year degree programmes in 2010) and in winter 2011-12, five-and-a-half years from the first survey. 
experience of internships. The findings in this chapter also draw on qualitative accounts provided by two respondents who were interviewed as part of the CGCS research outlined previously.

\subsection{FINDINGS FROM THE RESEARCH}

\subsubsection{The (Non)Developmental Character of Unpaid Internships}

One of the key themes in the literature about graduate internships is that they are, or should be, a way of developing employability and bridging the transition from education into the world of work. ${ }^{45}$ Internships are thought to provide valuable experience and help interns develop industry-specific skills, knowledge and networks. ${ }^{46}$ Indeed, the developmental nature of internships has been used by some policy-makers as a justification for not bringing internships explicitly within NMW legislation. ${ }^{47}$ This section presents quantitative data from the DLHE about the extent to which interns' higher education qualification was needed to obtain their job (arguably an indication of the level of skill needed for the role) and data from the CGCS on graduates' views on paid and unpaid graduate internships and their usefulness in the development of their subsequent careers.

The findings show that, while many report that their internships (paid or unpaid) have provided useful experience or have helped them to develop their careers - as has been shown elsewhere ${ }^{48}$ - unpaid internships are less likely than paid internships to be rated positively or to be of a level that requires a degree.

\subsubsection{Level, Usefulness and Developmental Benefits of Paid and Unpaid Graduate Internships}

The DLHE asks respondents to indicate whether their qualification was a requirement for the job, just an advantage or not needed (Figure 6.1). Those who were currently doing an unpaid internship at the time of the survey were much less likely than paid interns to say their qualification was a requirement

\footnotetext{
45 Perlin (n 8); Milburn (n 2); Gateways to the Professions Collaborative Forum (n 19); Lawton and Potter (n 10).

${ }_{46}$ CIPD, Internships (n 7); CIPD, Internships that Work (n 13); Mellors-Bourne and Day (n 38); Oakleigh Consulting and CRAC (n 13).

47 HC Deb 4 November 2016, vol 616, cols 1195-213; HL Deb 18 December 2017, vol 787, cols $1825-7$.

48 Eg Sabina Siebert and Fiona Wilson, 'All Work and No Pay: Consequences of Unpaid Work in the Creative Industries’ (2013) 27 Work, Empl \& Soc 711.
} 
(31 per cent compared with 51 per cent), and twice as likely to indicate their qualification was not needed ( 28 per cent compared with 14 per cent). They were also less likely to say it was a requirement than those who were working on a fixed-term contract, particularly those on longer fixed-term contracts. However, they were more likely to say that their qualification was needed or a requirement than those working in voluntary positions or those working freelance or setting up their own business. Thus, while unpaid graduate internships appear more likely to be of a level appropriate for a graduate than, for example, temping or genuine volunteering, they appear to be at a lower level than paid internships, which appear to require a degree more than nearly all other forms of employment.

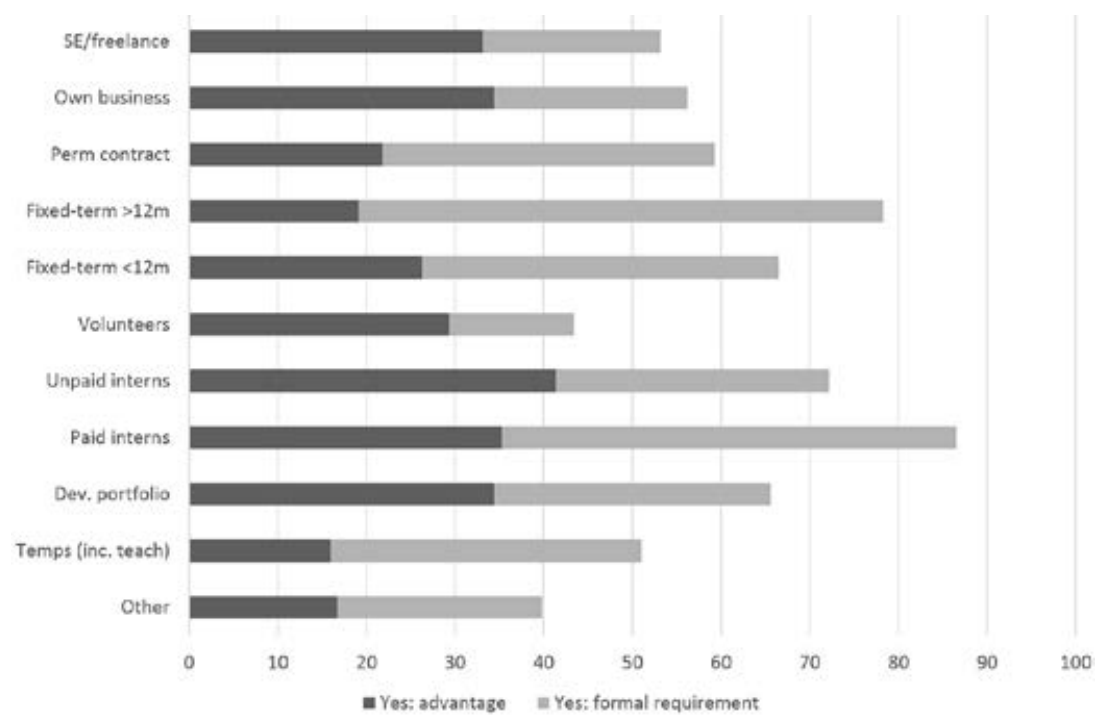

Note: Base - any evidence of work.

Source: Hunt (n 5); data - HESA Destination of Leavers survey 2011/12, Copyright Higher

Education Statistics Agency Limited 2013. The Higher Education Statistics Agency (HESA) cannot accept responsibility for any inferences or conclusions derived from the data by third parties.

Figure 6.1 Whether recent qualification was a requirement or just an advantage, by employment type (percentage)

In the CGCS, all creative and mass communications graduates were asked to rate on a scale of one to five how effective they felt different types of employment were for developing a range of work and career-related aspects: skills and knowledge, professional networks, ability to be creative, and career 
more generally (Figure 6.2). While paid internships were rated highly for development - second only to a permanent job for skills/knowledge, networks and career - unpaid internships were lower on all measures. Indeed, unpaid internships were rated lowest out of the types of employment listed on all four aspects of career development.

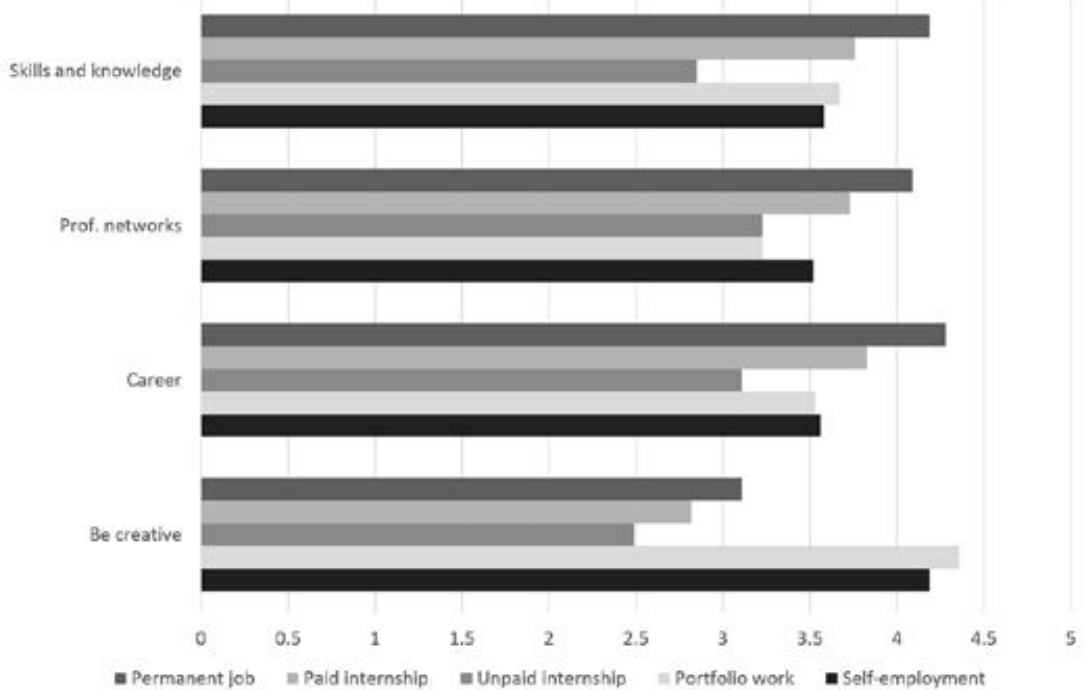

Note: Base - all respondents.

Source: Hunt (n 5); data - Creative Graduates Careers Survey.

Figure 6.2 Mean ratings for each employment type for each area of development

In the CGCS, not only were unpaid internships rated less highly for development, but they were less likely to be seen as useful by those who had engaged in them. While the majority ( 85 per cent) of those who had done an unpaid internship felt that they had been at least useful, and half (51 per cent) felt they had been very useful, they were much less likely than those with experience of paid internships to say they had been very useful (70 per cent) in the development of their career so far, and 14 per cent felt they had been no help at all (no one who had done a paid internship said they were of no help) (Figure 6.3). ${ }^{49}$

49 While these bivariate differences were found to be statistically significant at the 95 per cent level of confidence, they do not take account of differences in the personal and study characteristics of those who had done paid or unpaid internships. 


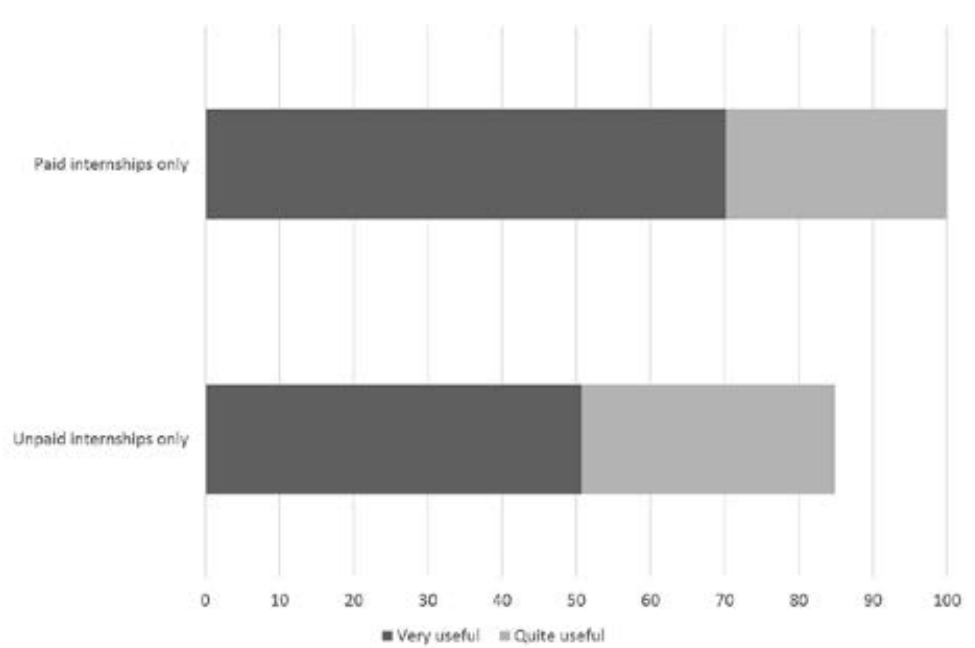

Note: Base - those with experience of internships at any point after graduation. Source: Data - Creative Graduates Careers Survey.

\section{Figure 6.3 Perceived usefulness of paid and unpaid internships (percentage)}

These quantitative findings were reflected in the qualitative data. Emily, a graduate in English and creative writing, completed a four-month unpaid internship in marketing after her degree which she 'created for herself'. She was advised by an employment agency to get some marketing-relevant experience if she wanted to pursue a career in marketing. Thus, she approached the employer directly, and offered her services for free with only her travel expenses being paid. She suggested that this internship was not a graduate role, but felt that experience was important and that unpaid work was often a prerequisite in the creative sector:

[M]ost companies would be quite happy to take on a graduate, for an internship for free, so, I mean there's lots of talk about, exploitative and how long is too long, and stuff like that ... I just thought right, I'm going to, to get this internship, get some experience under my belt.

This reflects the 'rite of passage' view expressed by graduates, particularly in the creative sector, in other studies. ${ }^{50}$ Interestingly, Emily did not specify

50 Eg Leslie Regan Shade and Jena Jacobson, 'Hungry for the Job: Gender, Unpaid Internships, and the Creative Industries' (2015) 63 Sociol Rev 188; Siebert and Wilson (n 48). 
whether these internships require a degree, but the latter is perceived as a 'guaranteed level of literacy', as she reported in the advice she would give to higher education students in relation to work experience: 'Obviously if there are internships out there that pay, perfect, but if not then companies are more than happy to get, you know, graduates with, you know, guaranteed levels of kind of, as I say, literacy.'

Nikki, an environmental studies and media graduate, had completed a total of five work placements and internships over the years, which comprised one sandwich placement and four open-market internships (three unpaid while studying and one paid graduate internship). These varied considerably in structure, tasks and development, ranging from 'stuffing envelopes' for a political party 1.5 days a week to structured project work. The paid internship she characterized as 'basically a proper job', but she felt the 'internship label' gave the employer a 'licence' to pay less and to make it part-time and/or short term. The first unpaid internship she felt was a waste of time but the other two (one paid and one unpaid) were more structured and developmental:

So the first one was pretty much stuffing envelopes. Then moving onto, so the OD [organizational development] consultancy one, it was doing a piece of research, desk research, writing it up into a report. So jumping back to [the branding consultancy], it was producing some guidelines for an NGO on messaging, analysing transcripts.

Nikki's experience perhaps underscores the importance of the extent to which internships offer a structured developmental experience. This is identified by Lain and others, who also note that unpaid open-market internships may be less likely than paid internships to be structured. ${ }^{51}$

\subsubsection{Do Unpaid Internships Provide a Bridge to Graduate Jobs?}

Another theme in the literature and policy debate on internships is that, paid or unpaid, they help labour-market entrants bridge the transition from education to employment. ${ }^{52}$ Indeed, concerns in the literature that unpaid internships may exclude those from less privileged backgrounds from accessing certain professions or industries implicitly assume that these internships provide a route into these industries. ${ }^{53}$

The multivariate analysis of CGCS data fails to support this view, ${ }^{54}$ at least as far as creative and mass communications graduates - two subjects

\footnotetext{
Lain and others (n 11).

Roberts (n 2); Milburn (n 2).

Montacute (n 2); Lawton and Potter (n 10).

Hunt, 'Internships' (n 5).
} 
with a high incidence of graduate internships - are concerned. Ordinary least squares regression and binary logistic regression were used to analyse the effects of paid and unpaid internship experience on earnings and occupational outcomes, while controlling for other factors including grades and institution prestige. ${ }^{55}$ There was no evidence to suggest that graduates with experience of unpaid internships were any more likely to have a creative or graduate-level job $^{56}$ than those without internship experience at the time of the survey (that is, two, four or six years after graduation). Furthermore, those with experience of unpaid internships after graduation earned substantially less on average than those without internship experience, other things being equal. Those with paid internship experience, however, were more likely to have a creative or graduate-level job and earned a substantial premium two, four or six years after graduation (Figure 6.4). The top panel of Figure 6.4 displays the effect (odds ratios) of having engaged in a work placement while studying or a paid or unpaid internship after leaving university on the propensity to have a professional-level or a creative job as a main job. The results show that, while holding other factors in the model constant:

- Having engaged in a work placement while studying increases the chances of having a professional-level job by nearly double, although the effect on creative jobs was not statistically significant.

- Having engaged in a paid internship after graduation more than doubles the chances of having a professional-level job, or having a creative job.

- The effect of having engaged in an unpaid internship on the propensity to have a creative or professional-level job was not found to be statistically significant.

Furthermore, when looking at earnings (the lower panel in Figure 6.4), paid internships were associated with a statistically significant increase in earnings, whereas having engaged in an unpaid internship was associated

55 See ibid for a full description of the multivariate analysis. Control variables included age, ethnicity, gender, parental experience of higher education (a proxy for social class), country or region of domicile, subject, classification of degree, cohort, league table score of higher education institution, and work placement experience while studying. Whether work was part-time and whether respondents had multiple jobs were also controlled for in the ordinary least squares regression.

56 These were: (1) a professional-level job (major groups 1-3 of the Standard Occupational Classification system: 'managers, directors and senior officials', 'professionals' and 'associate professional and technical'); or (2) a creative job, based on a definition developed in a major study of the early careers of creative and mass communications graduates. See Linda Ball, Emma Pollard and Nick Stanley, Creative Graduates, Creative Futures (Creative Graduates Creative Futures Higher Education Partnership 2010). 


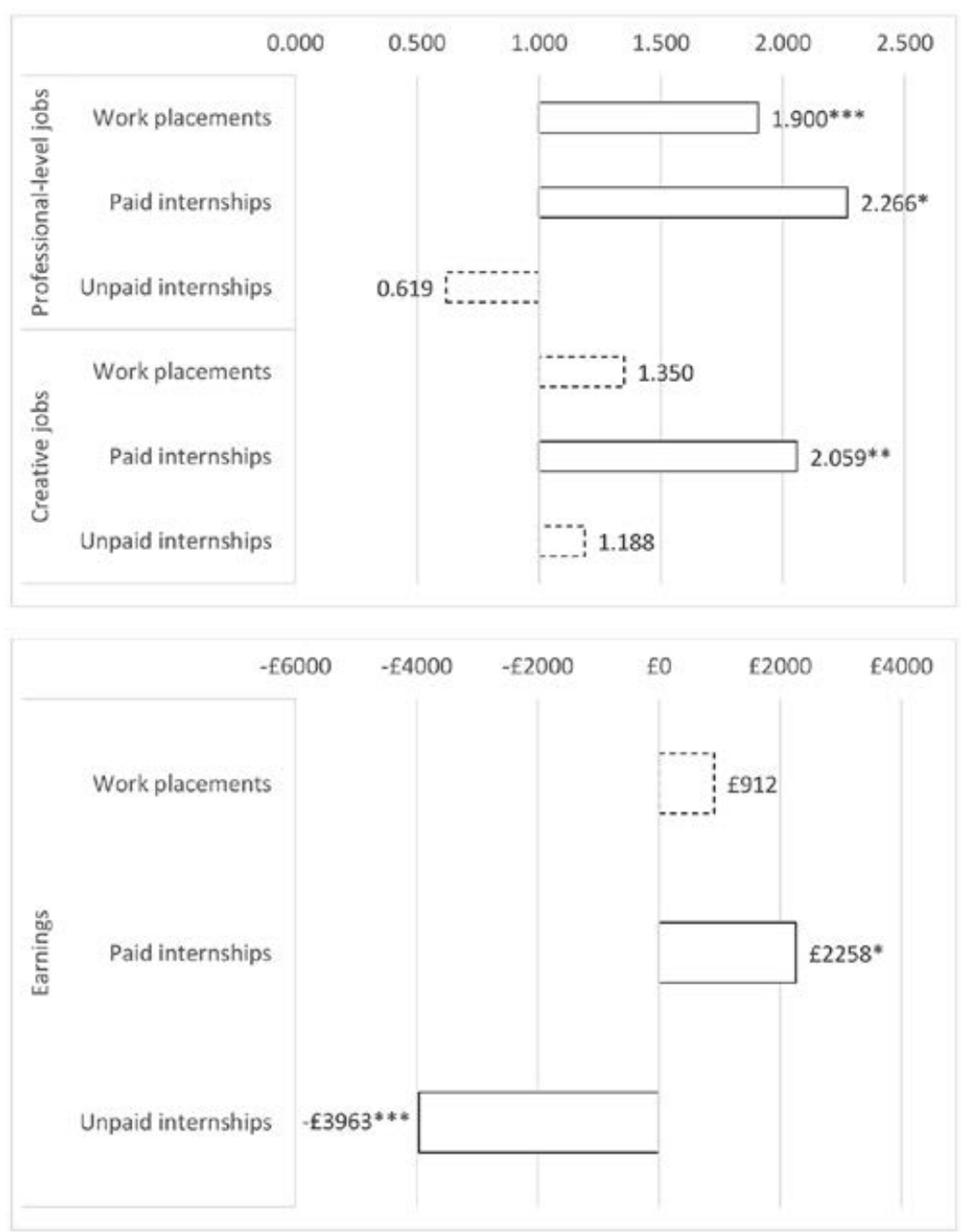

Notes: Base: all graduates in employment at the time of the survey; statistically significant at $* .05, * * .01, * * * .005$.

Source: Data - Creative Graduates Careers Survey.

Figure 6.4 Effect of work placements during study and paid and unpaid graduate internships on propensity to have a professional-level/creative job (odds ratios) and on earnings (£) 
with a statistically significant decrease in earnings relative to not having any internship experience. The size of the decrease in earnings associated with having unpaid internship experience was larger than the effect of two years in the labour market (£2823). These findings fail to support the assumption that unpaid graduate internships provide an invaluable bridge into graduate jobs, and appear to indicate that they may have a detrimental effect on earnings in the short to medium term (at least for creative and mass communications graduates). However, paid graduate internships and (on some measures) work placements do seem to improve the employability of graduates.

These findings fit with those of Purcell and others and Holford, who also found that unpaid work after graduation had a negative impact on graduate outcomes. ${ }^{57}$ Furthermore, while Cullinane and Montacute found that having engaged in one unpaid internship had a positive effect on outcomes, ${ }^{58}$ having engaged in multiple unpaid internships could have a negative effect.

The qualitative data provided mixed evidence. Emily reported that her unpaid internship in marketing along with her paid work experience in an office administrative position played a significant role in getting her job as a marketing sales assistant: "so that [paid office administration experience], combined with the kind of internship which was unpaid but gave me experience in marketing, um, the two combined were what led me to get the job that I currently have'.

On the contrary, Chloe, a graduate in archaeology, did an unpaid internship at a museum which did not lead to developing her career. She currently works as an administrator. However, the internship made her realize that she was more interested in people-facing jobs in the heritage sector, but she recognized that there were limited job opportunities in this competitive sector. Moreover, she highlighted the limited benefits that an individual can receive from an ongoing two-week placement scheme (open to students and graduates):

When I was working at the museum and art gallery in [city], and I was doing the $\mathrm{X}$ work, the conserving of objects, that was an ongoing placement, so they'd have one student for two weeks and then the next student for two weeks and then the next student for two weeks. So I was one of sort of many.

Nikola had an interdisciplinary degree (politics and languages) with unpaid and paid experience in think tanks during his studies. He obtained a paid internship for six months after graduation in a Brussels-based consultancy (he had to supplement his income with savings in order to live in Brussels). He explained how internships are being utilized for longer-term employment

57 Purcell and others, Futuretrack Stage 4 (n 40); Holford (n 41).

58 Cullinane and Montacute (n 6). 
in this organization to test and select employees, as auditions. ${ }^{59}$ He benefited from these auditions himself, as he was employed as a political communication and policy analyst by the organization after the internship.

Similarly, Sally, a languages graduate, completed a paid internship in a European country providing translating services. While the organization wanted to keep her after the end of the internship, they could only provide an intern's earnings, which were too low for her to stay in a foreign country. However, after she returned to the UK, she continued working with the organization as a freelancer translator using contacts and networks developed during her internship. While the internship did not directly lead to a paid job at the organization, the contacts and experience were helpful in obtaining other work, albeit of a more precarious nature. This example also shows how interns may suffer a pay penalty in the short to medium term, as the period working for no or low pay may put them in a weak bargaining position moving into paid work and/or may hinder pay progression.

There was an expectation that internships, particularly graduate internships, would or should lead to something, even if it was not a job at the organization. This is what Nikki, an environmental studies and media graduate, had to say about graduate internships:

I would absolutely trust that it would lead to something. I wouldn't necessarily expect them to give me a job afterwards, I'd expect from them that they would have the intention and keenness to connect me and get me involved in the industry ... not just that they are using me as a resource for however many months and then, 'See you later. We haven't got a job for you.' It shouldn't be about, 'We've got a bunch of crap that needs doing, and if they don't perform we kick them out in the most brutal way possible', which happens.

Overall, these qualitative accounts provide a mixed picture of the value of unpaid open-market internships after graduation and the extent to which they provide a reliable bridge into meaningful employment.

\subsection{DISCUSSION AND IMPLICATIONS FOR PUBLIC POLICY AND REGULATION}

Owens and Stewart have identified five strategies for the regulation of open-market internships used in different national jurisdictions: specific regulation, regulation by inclusion, regulation by exclusion, application of

59 Vicki Smith, 'Enhancing Employability: Human, Cultural, and Social Capital in an Era of Turbulent Unpredictability' (2010) 63 Hum Rel 279. 
general-law and soft-law approaches. ${ }^{60}$ In the UK, while the regulatory framework would allow for a general-law approach, lack of effective enforcement of labour regulations means that the approach can most accurately be categorized as a soft-law approach ${ }^{61}$ Recent evidence showing that the proportion of unpaid internships may be declining suggests that this approach has had some limited success. ${ }^{62}$ However, the extent to which further progress is possible on the issue of the quality and prevalence of unpaid internships is unclear. While the existing voluntary codes of practice provide useful guidance, confusion about the legal status of internships and the apparent lack of political will and resources to enforce existing regulations means that less conscientious employers may be unlikely to change their ways.

The findings presented in this chapter suggest that, while paid open-market internships after graduation help develop employability and lead to positive labour-market outcomes, unpaid open-market internships are less likely to provide the same benefits. Unpaid internships are not so developmental or instrumental, for example, they do not improve the chances of having a creative or graduate-level job and/or they lead to reduction in earning power. Here we discuss the implications of this for each of the remaining four approaches to regulation identified by Owens and Stewart.

Regulation by exclusion would see internships defined and specifically excluded from existing labour regulations in much the same way as work placements linked to an educational course currently are. This would presumably have the benefit of not deterring employers from offering such positions, but would arguably weaken the existing rights of interns and lead to further exploitation, potentially displacing paid entry-level workers and driving down wages. In addition, under this approach interns would not enjoy the same level of governance or financial support enjoyed by university students on a work placement, cited by Lain and others as one of the benefits of governed placements. ${ }^{63}$ One of the recommendations of the Panel for Fair Access to the Professions was to extend student loans to cover a period after graduation for engaging in internships. ${ }^{64}$ However, this would arguably mean the government effectively subsidizing employers to offload their responsibilities for developing labour-market entrants in alignment with wider labour-market trends, linked to changes in the global economy. ${ }^{65}$

\footnotetext{
60 Owens and Stewart (n 17).

${ }_{61}$ Stewart and others (n 17); Owens and Stewart (n 17).

62 Hunt, Participation (n 4).

63 Lain and others (n 11).

64 Milburn (n 2).

65 Paul Thompson, 'Financialization and the Workplace: Extending and Applying the Disconnected Capitalism Thesis' (2013) 27 Work, Empl \& Soc 472; Smith (n 59).
} 
An alternative approach would be to introduce specific legislation to govern internships. The Chartered Institute of Personnel and Development (CIPD) initially recommended bringing internships in line with apprenticeships, instituting a new 'training wage' for interns at a much lower rate of NMW than for 'workers' (currently $£ 3.90$, compared with $£ 7.70$ for 21 - to 24 -year-olds and $£ 8.21$ for those aged 25 or over $\left.{ }^{66}\right)$. Lawton and Potter criticized this proposal, arguing that many unpaid interns would be considered workers under the current rules and therefore eligible for the NMW at the higher rate. ${ }^{67}$ Furthermore, they noted that formal apprenticeships lead to a recognized qualification, unlike unpaid internships, and that the recommendations would unfairly discriminate against those wishing to work in industries with no recognized entry-level routes. Interestingly, subsequent CIPD guidance on internships withdrew the recommendation for a 'trainee rate' of the NMW, instead extolling the virtues (for employers and interns) of paying interns at least the NMW. ${ }^{68}$ More recently, Cullinane and Montacute have recommended explicitly banning internships of longer than four weeks. ${ }^{69}$ While this would potentially minimize the financial impact on unpaid interns, and deter their long-term exploitation, it could lead to a revolving door of unpaid, exploitative and non-developmental internships. ${ }^{70}$

Regulation by inclusion might be an alternative approach. Extending laws to include interns as workers or employees would ensure they receive at least the NMW, and discrimination and health and safety protections, and would encourage employers to make sure internships are structured and developmental. This would see internships specifically defined and brought within existing legislation and is, arguably, what the private members bill that was brought to Parliament sought to achieve. ${ }^{71}$ As noted previously, the Bill was ultimately 'talked out' by those opposing the legislation because they did not want to deter employers from offering such 'invaluable' opportunities. ${ }^{72}$ While some unpaid internships may well provide invaluable opportunities, the findings presented in this chapter make clear that this is not always the case. Bringing internships explicitly within existing legislation would clarify the status of internships for interns and employers and, as has been argued elsewhere, may

66 UK Government, 'National Minimum Wage and National Living Wage Rates' (Gov.UK), https://www.gov.uk/national-minimum-wage-rates, accessed 30 March 2021.

Lawton and Potter (n 10).

CIPD, Internships that Work (n 13).

Cullinane and Montacute (n 6).

McLeod and others (n 8).

National Minimum Wage (Workplace Internships) Bill 2016-17.

HC Deb 4 November 2016, vol 616, cols 1195-1213. 
lead employers and interns alike to invest more in the internship, to mutual benefit. ${ }^{73}$ In the House of Commons debate, some members argued that bringing internships explicitly within the NMW may deter some employers from offering internships. The findings presented in this chapter cannot attest to this, but it is likely to be true for some, particularly smaller, employers. However, this assumes that labour-market entrants need opportunities for labour-market experience more than employers need highly motivated and educated new workers. Arguably, in a time of rapid technological change, employers may need graduate skills more than ever.

Finally, the application of the general-law approach would see greater enforcement of current labour-market protections. Arguably, the framework for this exists in UK law. However, the total lack of cases brought by the UK authorities means that enforcement effectively comes down to whether unpaid interns have the resources and are prepared to bring a case against their employer. For aspirants hoping to gain a foothold in a certain industry or profession, there are strong disincentives to do so. An example where a more robust approach to the application of general law has been attempted is the work of the Fair Work Ombudsman (FWO) in Australia. As in the UK, in Australia, while there are exemptions for placements linked to an educational course and for volunteering, the legal position of internships is not entirely straightforward and often comes down to whether a contract to perform work is in place. ${ }^{74}$ According to Stewart and others, the FWO is the only example where 'a government agency has systematically and publicly pursued sanctions against businesses or other organizations involved in the use of potentially unlawful internships ${ }^{75}$ A number of cases have been successfully brought by the FWO, resulting in fines for a number of organizations. It is hard to assess the impact that this noncompliance work, together with the wider awareness and public engagement work that the FWO does, has had on the incidence and quality of unpaid internships. However, cases such as these are likely to have more of a deterrent effect than the current level of enforcement carried out by HM Revenue and Customs in the UK. However, this type of enforcement will require more resources, and political will.

In summary, there are costs and benefits in the above-mentioned regulation approaches and there is not a clear route forward. However, given the evidence presented in this chapter, it is clear that the status quo is unsustainable. Whichever approach to the regulation of internships is adopted, at the very least a clearer definition of the boundaries between work placements (linked

\footnotetext{
73 Lain and others (n 11); CIPD, Internships that Work (n 13).

74 Stewart and others (n 17).

75 Ibid 41.
} 
to a formal course of education), open-market internships and genuine volunteering would be desirable. A clear definition of internships is essential to understand differences between internships, volunteering roles, placements and work experience, and the advantages and disadvantages they entail. 